\title{
Global proteomic analysis of plasma from mice infected with Plasmodium berghei ANKA using two dimensional gel electrophoresis and matrix assisted laser desorption ionization-time of flight mass spectrometry
}

\author{
Evelyn N Gitau ${ }^{1,2^{*}}$, Gillbert O Kokwaro ${ }^{4,5,6}$, Charles RJC Newton ${ }^{1,3}$ and Stephen A Ward ${ }^{2}$
}

\begin{abstract}
Background: A global proteomic strategy was used to identify proteins, which are differentially expressed in the murine model of severe malaria in the hope of facilitating future development of novel diagnostic, disease monitoring and treatment strategies.

Methods: Mice (4-week-old CD1 male mice) were infected with Plasmodium berghei ANKA strain, and infection allowed to establish until a parasitaemia of 30\% was attained. Total plasma and albumin depleted plasma samples from infected and control (non-infected) mice were separated by two-dimensional gel electrophoresis (2-DE). After staining, the gels were imaged and differential protein expression patterns were interrogated using image analysis software. Spots of interest were then digested using trypsin and the proteins identified using matrix-assisted laser desorption and ionization-time of flight (MALDI-TOF) mass spectrometry (MS) and peptide mass fingerprinting software.
\end{abstract}

Results: Master gels of control and infected mice, and the corresponding albumin depleted fractions exhibited distinctly different 2D patterns comparing control and infected plasma, respectively. A wide range of proteins demonstrated altered expression including; acute inflammatory proteins, transporters, binding proteins, protease inhibitors, enzymes, cytokines, hormones, and channel/receptor-derived proteins.

Conclusions: Malaria-infection in mice results in a wide perturbation of the host serum proteome involving a range of proteins and functions. Of particular interest is the increased secretion of anti-inflammatory and anti apoptotic proteins.

\section{Background}

Malaria continues to affect millions of people in subSaharan Africa, where severe falciparum malaria is a major cause of childhood mortality. The malaria parasite infects 300-500 million people per year, causing over 1 million deaths [1]. In light of this, there is a need to better understand the biochemical changes associated with

\footnotetext{
* Correspondence: egitau@kilifi.kemri-wellcome.org

'KEMRI-Wellcome Trust Collaborative Programme, Centre for Geographic Medicine Coast, Kilifi, Kenya

Full list of author information is available at the end of the article
}

severe malaria as the definitive cause of death is often unknown.

Animal models of cerebral malaria have been developed to provide insight in to the pathogenesis of the disease although it is accepted that there are differences from the human condition. Cerebral malaria is induced in susceptible strains of mice by the ANKA strain of Plasmodium berghei [2]. These murine models of cerebral malaria have been used in the past to throw light on the pathogenesis of the human condition [3-6].

Proteome analysis is the direct measurement of all proteins in a system in terms of their presence and

\section{C) Biomed Central}


relative abundance at a specific point in time under defined conditions. Proteomics is regarded as complimentary technology to genome analysis. Proteins contain several dimensions that collectively indicate the actual rather than the potential functional state as indicated in mRNA analysis. Although the pattern of gene activity will be abnormal in a tissue with pathological lesions, there can be poor correlation between the level of activity of different genes and the abundance of their corresponding proteins within tissues [7]. Proteomic studies characterize the complex network of cell regulation at the protein level.

Here, the use of a global proteomic strategy to identify proteins differentially expressed in the murine model of cerebral malaria is reported. This work was conducted in order to identify opportunities for the development of novel diagnostic, disease monitoring techniques, and possible future treatments.

\section{Methods}

\section{Mouse samples}

Plasma was collected from 4-week-old CD1 male mice $(\mathrm{n}=3)$ infected with the ANKA (PbA) strain of P. berghei originally obtained from the London School of Tropical Medicine and Hygiene $(0.1 \mathrm{ml}$ of a culture with $2 \%$ parasitaemia). A control set of plasma was collected from mice $(n=2)$ without infection. The samples were separated into two aliquots and albumin was depleted from one aliquot using the Montage Albumin kit (Millipore, USA). Proteomic analysis was carried out separately on each sample.

The use of mice in these experiments was undertaken in accordance with criteria outlined in a license granted under the Animals (Scientific Procedures) Act of 1986 and approved by the University of Liverpool Animal Ethics Committee.

\section{Two-dimensional electrophoresis (2-DE)}

The first separation (first dimension) was carried out on a Multiphor II flat bed electrophoresis system (Pharmacia Biotech, Uppsala, Sweden). Ready-made strips Immobiline Drystrip gels (IPG) with a $\mathrm{pH}$ gradient 3-10 NL (non-linear) $13 \mathrm{~cm}$ long (Amersham Pharmacia Biotech, Bucks, UK) were used. The strips were passively rehydrated overnight at room temperature with a rehydration buffer (8 M Urea, 3\% CHAPS, 0.5\% IPG buffer 3-10, $10 \mathrm{mM}$ DTT, and a trace amount of bromophenol blue), which contained $75 \mu \mathrm{g}$ of plasma protein for preparative gels and $300 \mu \mathrm{g}$ for analytical gels. Isoelectric focusing was carried out using multi-step conditions (1 $\mathrm{h}$ at $150 \mathrm{~V}, 1 \mathrm{~h}$ at $300 \mathrm{~V}, 1 \mathrm{~h}$ at $1500 \mathrm{~V}, 18 \mathrm{~h}$ at $3000 \mathrm{~V})$. Before the second dimension each strip was equilibrated by incubating for 15 minutes at room temperature in 10 $\mathrm{ml}$ of equilibration buffer (50 mM Tris- $\mathrm{HCl}, \mathrm{pH} 8.8,6$
M urea, 30\% w/v glycerol, 2\% w/v SDS and a trace of Bromophenol Blue) with $1 \%$ w/v DTT. A second equilibrating step of 15 minutes was performed in $10 \mathrm{ml}$ equilibration buffer containing $4 \% \mathrm{w} / \mathrm{v}$ iodoacetamide. The second dimension was performed on home made $12.5 \%$ homogenous vertical SDS-polyacrylamide gel slabs (gel plate size $180 \times 160 \mathrm{~mm}$ and a gel thickness $1.5 \mathrm{~mm}$ ) employing a Laemmli buffer system[8]. Electrophoresis was performed at $20^{\circ} \mathrm{C}$ under a constant current of $25 \mathrm{~mA}$ per gel using a Hoefer SE 600 series vertical slab gel electrophoresis unit (Amersham Pharmacia Biotech, Bucks, UK).

\section{Protein visualization and image analysis}

Analytical gels were silver stained using a protocol described by Blum et al [9] with modifications described by Rabilloud et al [10]. Preparative gels were stained using colloidal Coomassie Brilliant Blue G-250 as previously described by Neuhoff et al [11]. The stained gels were scanned using a GS-710 Imaging Densitometer (BioRad, Hemel Hempstead, Hertfordshire UK). The gels were analysed using PDQuest ${ }^{\circledR}$ software version 6.2.1 (Bio Rad, Hemel Hempstead, Hertfordshire UK) and Progenesis PG $220^{\circledR}$ V2006 software (Nonlinear Dynamics, Newcastle upon Tyne, UK). PDQuest ${ }^{\mathbb{B}}$ enabled the matching of identical spots in serial gels and normalization of gels to compensate for nonexpression related variations in protein spot intensity. The software also enabled the tracking and reporting of all the protein patterns in the samples. By using the comparison tool for master gels, the software facilitated the comparison of differences between malaria infected and control groups. Semi-quantitative analysis of spots was performed using Progenesis PG220 ${ }^{\circledR}$.

\section{Tryptic in-gel digestion}

Eppendorf tubes and all utensils were cleaned with $50 \% \mathrm{v} / \mathrm{v}$ acetonitrile $/ 0.1 \% \mathrm{v} / \mathrm{v}$ TFA solution and dried. The protein spots of interest identified on preparative gels were excized and transferred to the Eppendorf tubes. The chopped gel pieces were washed in $50 \%$ acetonitrile $/ 25 \mathrm{mM}$ ammonium bicarbonate, $\mathrm{pH} 7.8$, and dried in a vacuum concentrator. Then 4-10 $\mu \mathrm{l}$ digestion buffer $(10 \mu \mathrm{g} / \mathrm{ml}$ modified sequencing grade trypsin (Promega) in $25 \mathrm{mM}$ ammonium bicarbonate) was added to the dried gel pieces and incubated overnight at $37^{\circ} \mathrm{C}$. Resulting peptides were extracted by addition of $4 \mu \mathrm{l}$ water followed by $7 \mu \mathrm{l} 30 \%$ acetonitirile/ $0.1 \%$ TFA followed by vortexing and brief centrifugation. The supernatant was transferred to a clean tube and vacuum concentrated to approximately $5 \mu \mathrm{l}$.

\section{Mass spectrometric identification of proteins}

The concentrated sample $(0.5 \mu \mathrm{l})$ was directly applied onto the sample target plate with equal amounts of 
matrix (10 $\mathrm{mg} / \mathrm{ml} \alpha$-cyano-4-hydroxycinnamic acid (HCCA; Aldrich) in 50\% acetonitrile/0.1\% TFA). Mass spectra were obtained using MALDI-MS (Shimadzu CFR Plus, Manchester UK) in positive ion reflectron mode at an accelerating voltage of $20 \mathrm{kV}$. The spectra were externally calibrated using a peptide mixture (Sigma, St Louis, MO) with masses 757.39 (Bradykinin), 1046.54 (Angiotensin II) and 2465.19 (ACTH). Spectra obtained were used to search through the NCBI nr database using the MASCOT Peptide Mass Fingerprinting software [12] (with a tolerance of $\sim+/-0.1 \mathrm{D}$ and one missed cleavage site.

\section{Results}

\section{Protein separation by 2-DE}

Plasma samples from infected mice together with control samples were applied to 2-DE and proteins visualized by silver stain for analytical gels and Coomassie blue stain for preparative gels. Representative gel maps for plasma from infected mice, and control mice before and after albumin depletion were created using PDQuest ${ }^{\circledR}$. The gel maps are synthetic gels prepared by analysing four replicate silver stained gels of each sample. Representative gel master gels of controls, infected, albumin depleted control and infected had 752, 639, 921 , and 610 spots respectively. Individual variation was calculated using PDQuest and extent of correlation of protein spots between the replicate gels was reported as correlation coefficients. For all gel maps, correlation between the individual gels was greater than 0.772 . A coefficient of 1.00 indicates that two gels are perfectly similar, while a low coefficient (e.g. 0.40) indicates the two gels are not very similar. There were protein spots that were differentially expressed on the gel of plasma from infected mice and some proteins were completely absent. Removing albumin improved the quality of gels and helped identify some additional spots of interest.

\section{Mass spectrometry and protein identification}

When stained with Coomassie between 60 and 104 spots per gel were visualized. Figure 1 shows the spots excized from the Coomassie stained gels. These spots were digested and prepared for MALDI analysis. It was possible to definitively identify $51,63,30$ and 18

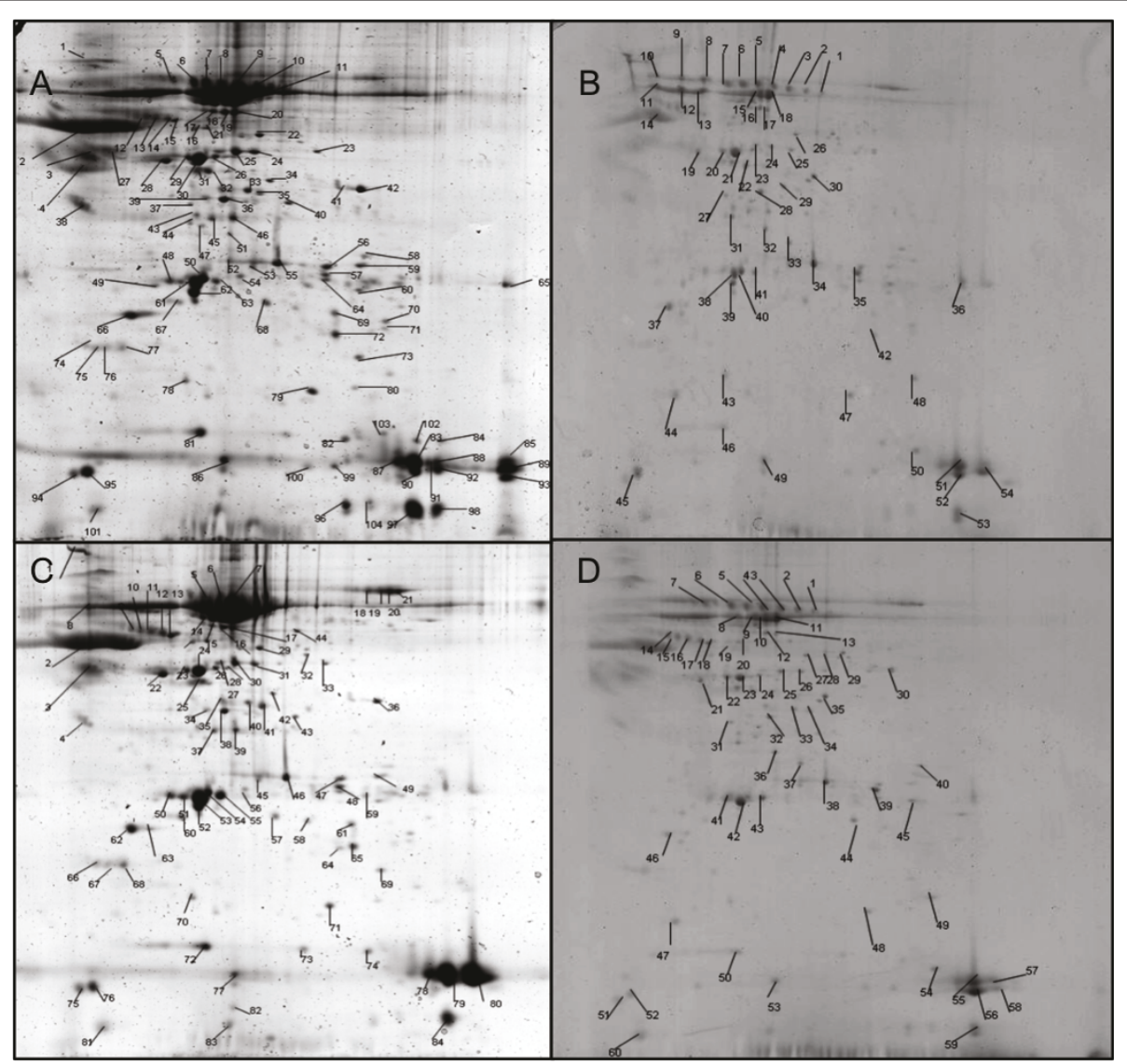

Figure 1 Coomassie stained 2-D PAGE gel of plasma from mice after loading with $\mathbf{3 0 0} \boldsymbol{\mu g}$ of sample protein. Plasma from infected mice (A), albumin depleted plasma from infected mice (B), plasma from control mice (C) and albumin depleted plasma from control mice (D). 
proteins from the infected, control, albumin depleted infected and albumin depleted control plasma samples respectively. Tables 1 and 2 give a list of these uniquely expressed proteins.

In accordance with the cut-off score recommended by Mascot ${ }^{\circledR}$ for Rodents a protein score of 63 was considered to be significant. Removing albumin improved the quality of gels and helped identify additional proteins. Semi-quantitative differential analysis was done on silver stained replicate gels using Progenesis PG $220^{\circledR} 2 \mathrm{DE}$ software. Spots were given a match number if 3 out of 4 replicates matched perfectly. Spots matched to each representative gel were then analysed for any changes in intensity.

\section{Functional cataloguing of proteins}

Protein functions were identified using the Protein Information Resource (PIR) id-mapping tool and catalogued according to their gene ontology (GO) number. The software enabled us to identify the molecular functions, cellular components and biological processes of the proteins. Figures 2 and 3 show a graphic breakdown of identified proteins according to their GO functional categories.

\section{Discussion}

Animal models have been developed to provide insights into the pathogenesis and neurological complications of malaria. Mouse models have been studied most extensively to examine the function of the blood brain barrier in malaria. Pathology of the Plasmodium berghei ANKA mouse model used in this study develops neurological signs, such as ataxia, hemiplegia and coma [13], clinical features which are seen in human CM. However, in contrast to human CM, there is little evidence of sequestration of parasitized red blood cells (PRBCs) in the brain [14], but rather monocytes and non-PRBCSs predominate [5]. However, recent studies have found PRBCs in the cerebrum and cerebellum of infected mice [15].

Although the pathogenesis of the neurological complications of murine malaria appears to be more inflammatory $[14,15]$ than in human malaria, changes in protein

Table 1 List of proteins identified from the Coomassie stained gels of plasma from infected mice (Figure 2)

\begin{tabular}{|c|c|c|c|c|c|}
\hline Spot No. & Description & Accession & Score & $\begin{array}{l}\text { Matched } \\
\text { Peptides }\end{array}$ & $\begin{array}{l}\text { Sequence } \\
\text { coverage(\%) }\end{array}$ \\
\hline 1 & $\begin{array}{l}\text { serine (or cysteine) proteinase inhibitor, clade A, member 1a; } \\
\text { serine protease [Mus Musculus] }\end{array}$ & 15029662 & 83 & 8 & 26 \\
\hline 12,14 & $\begin{array}{l}\text { similar to macrophage galactose-type C-type lectin } 2 \text { [Mus } \\
\text { Musculus] }\end{array}$ & 38089618 & 78,68 & 7,6 & 21,20 \\
\hline 36 & $\begin{array}{l}\text { similar to spectrin alpha chain, brain (spectrin, non-erythrid } \\
\text { alpha chain) }\end{array}$ & 38074605 & 71 & 10 & \\
\hline 42 & $60 S$ ribosomal protein $\mathrm{L} 35 \mathrm{a}$ & 3914537 & 70 & 5 & 31 \\
\hline $\begin{array}{l}48,50,56,72 \\
94,95\end{array}$ & apolipoprotein A-1 precursor - mouse & 109571 & $\begin{array}{l}137 \\
102,87,72,64,65\end{array}$ & $\begin{array}{l}11,9,8,7,7 \\
6\end{array}$ & $\begin{array}{l}34,29,27,23 \\
19,19\end{array}$ \\
\hline $\begin{array}{l}48,50,56,67 \\
72,94,95\end{array}$ & unamed protein product [Mus Musculus] & 26345182 & $\begin{array}{l}136,102,87,76 \\
72,64,65\end{array}$ & $\begin{array}{l}11,9,8,8,7 \\
7,6\end{array}$ & $\begin{array}{l}34,29,27,28 \\
23,19,19\end{array}$ \\
\hline $48,50,56,94,95$ & apolipoprotein A-1 [Mus Musculus] & 2145135 & $119,86,72,64,65$ & $10,8,7,7,6$ & $29,24,22,19,19$ \\
\hline 48,94 & apolipoprotein A1 homolog [mus sp.] & 1245804 & 69,66 & 5,7 & 53,53 \\
\hline 55 & unamed protein product [Mus Musculus] & 26341396 & 80 & 9 & 20 \\
\hline 55 & albumin 1; serum albumin variant [Mus Musculus] & 33859506 & 78 & 9 & 19 \\
\hline 55 & serum albumin precursor & 5915682 & 78 & 9 & 19 \\
\hline 65 & similar to 60S Ribsomal protein L29 (P23) [Rattus Norvegicus] & 34866986 & 67 & 6 & 28 \\
\hline 66 & RNA binding motif protein, $\mathrm{X}$ chromosome [Mus Musculus] & 6755296 & 72 & 8 & 16 \\
\hline 66,103 & heterogenous nuclear ribonucleoprotein G [Mus Musculus] & 5579009 & 68,67 & 7,7 & 20,15 \\
\hline 66 & unamed protein product [Mus Musculus] & 26339834 & 66 & 9 & 10 \\
\hline 80 & similar to 60S Ribsomal protein L29 (P23) [Mus Musculus] & 38089196 & 78 & 7 & 25 \\
\hline 80 & similar to 60S Ribsomal protein L29 (P23) [Rattus Norvegicus] & 34881340 & 71 & 7 & 30 \\
\hline 81 & unamed protein product [Mus Musculus] & 26335691 & 69 & 7 & 25 \\
\hline 81 & heparan sulfate 6-0-sulfotransferase 1 [Mus Musculus] & 20845347 & 64 & 6 & 28 \\
\hline 82 & similar to HRPAP20 short form [Rattus Norvegicus] & 34867098 & 65 & 6 & 20 \\
\hline 99 & similar to Rp17a protein [Rattus Norvegicus] & 34868324 & 86 & 9 & 16 \\
\hline
\end{tabular}

The MALDI spectra were searched against the NCBInr database using the Mascot ${ }^{\mathbb{B}}$ search algorithm. Proteins with a significant score as defined by Mascot ${ }^{\mathbb{B}}$ were included in the list. 
Table 2 List of proteins identified from the Coomassie stained gels of plasma from control mice

\begin{tabular}{|c|c|c|c|c|c|}
\hline Spot No. & Description & Accession & Score & $\begin{array}{l}\text { Matched } \\
\text { Peptides }\end{array}$ & $\begin{array}{c}\text { Sequence } \\
\text { coverage }(\%)\end{array}$ \\
\hline $\begin{array}{c}7,23,24,46,70 \\
71\end{array}$ & albumin 1; serum albumin variant [Mus Musculus] & 33859506 & $\begin{array}{c}104,104,92,136,77 \\
76\end{array}$ & $\begin{array}{c}11,11,11,14 \\
9,9\end{array}$ & $\begin{array}{c}22,22,25,26,18 \\
17\end{array}$ \\
\hline 22 & apolipoprotein A-IV [M. musculus] & 29477189 & 80 & 8 & 26 \\
\hline 28 & hypothetical protein XP_125606 [Mus Musculus] & 20858591 & 65 & 7 & 22 \\
\hline 30 & lectin, galactose binding, soluble 7 [Mus Musclus] & 31543120 & 66 & 6 & 36 \\
\hline 35 & $\begin{array}{l}\text { similar to } 605 \text { ribosomal protein L7a (Sufeit locus } \\
\text { protein 3) PLA-X polypeptide }\end{array}$ & 34869618 & 64 & 6 & 29 \\
\hline 40 & $\begin{array}{c}\text { polyadenlate-binding protein } 4 \text { (PABP 4) [Rattus } \\
\text { Novegicus] }\end{array}$ & 27690704 & 81 & 11 & 16 \\
\hline 44 & hypothetical protein XP_218509 [Rattus Norvegicus] & 34855811 & 72 & 9 & 9 \\
\hline 46 & unamed product [Mus Musculus] & 2614396 & 140 & 14 & 26 \\
\hline $\begin{array}{l}50,53,54,55,61 \\
62,64,65 \\
\end{array}$ & unamed product [Mus Musculus] & 26345182 & $\begin{array}{c}64,123,139,92,153 \\
118,63,86\end{array}$ & $\begin{array}{c}7,11,12,9,12 \\
10,6,8\end{array}$ & $\begin{array}{c}24,35,38,29,31 \\
35,18,29\end{array}$ \\
\hline 51 & Non0/p54nrb homolog [Rattus Norvegicus] & 2674209 & 71 & 6 & 23 \\
\hline 51 & stress-induced phosphoprotein 1 [Mus Musculus] & 13277819 & 69 & 9 & 9 \\
\hline 52 & cytochrome c oxidase subunit VIIc [Mus Musculus] & 6680991 & 70 & 5 & 36 \\
\hline $\begin{array}{c}53,54,55,61,62 \\
64,65\end{array}$ & apolipoprotein A-1 [Mus Musculus] & 6753096 & $\begin{array}{c}123,139,68,153,118 \\
63,86\end{array}$ & $\begin{array}{c}11,12,9,12 \\
10,6,8\end{array}$ & $\begin{array}{c}35,38,29,31,30 \\
18,29\end{array}$ \\
\hline 67,68 & major urinary protein [mice] & 1839508 & 85,163 & 7,11 & 36,42 \\
\hline 67 & similar To RIKEN Cdna 1700001 e04 [Mus Musculus] & 38076876 & 62 & 6 & 21 \\
\hline 70 & albumin [Mus Musculus] & 26986064 & 80 & 7 & 38 \\
\hline 71 & 60S Ribosoml protein L4 (L1) & 3914699 & 78 & 6 & 39 \\
\hline 72 & transthyretin [Mus Musculus] & 7305599 & 97 & 7 & 20 \\
\hline 72 & unamed product [Mus Musculus] & 12852317 & 64 & 5 & 34 \\
\hline 75 & $\begin{array}{l}\text { similar to hypothetical protein FLJ25333 [Mus } \\
\text { Musculus] }\end{array}$ & 38075385 & 68 & 7 & 17 \\
\hline 75 & $\begin{array}{l}\text { RNA binding motif protein, } X \text { chromosome [Mus } \\
\text { Musculus] }\end{array}$ & 6755296 & 64 & 7 & 13 \\
\hline $77,78,79$ & Hemoglobin beta subnit 1 [Mus Musculus] & 31982300 & $72,74,93$ & $6,6,7$ & $41,41,61$ \\
\hline 89 & $\begin{array}{l}\text { heterogenous nuclear ribonucleoprotein G [Mus } \\
\text { Musculus] }\end{array}$ & 5579009 & 67 & 7 & 18 \\
\hline
\end{tabular}

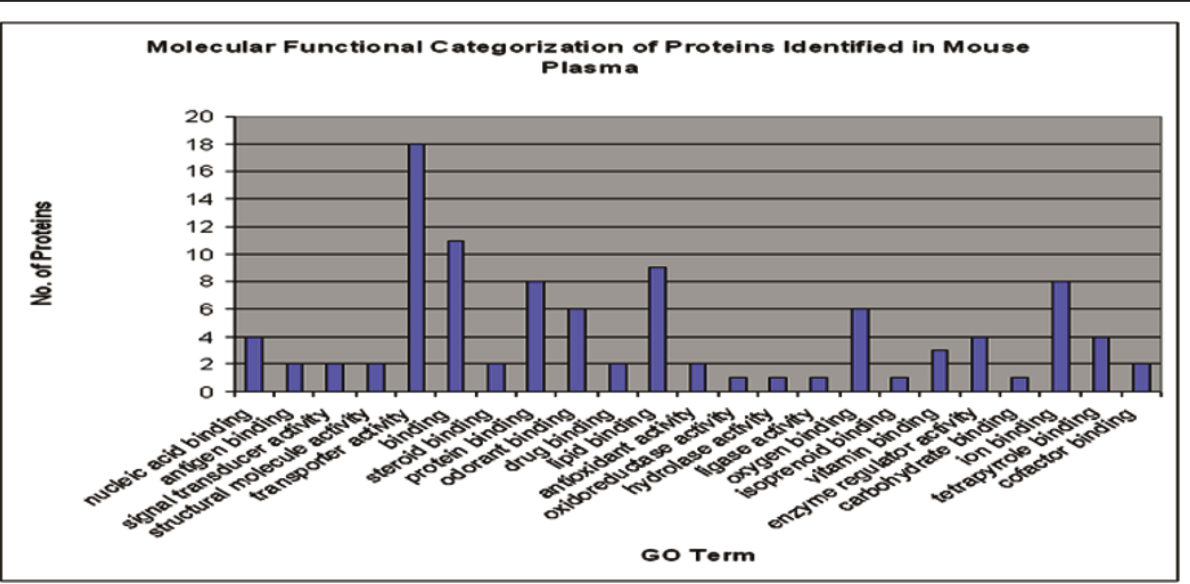

Figure 2 Functional Categorization of 106 proteins identified based on gene ontology classification for Molecular Function. The Gene Ontology (GO) numbers were derived from Protein Information Resource (PIR) -http://pir.georgetown.edu/ Batch retrieval tool. This tool converted the GI NCBInr accession numbers to GO numbers and then used GO slim to categorize the proteins. Another 47 identified proteins were unmatched to $\mathrm{GO}$ and not included in this graph. 


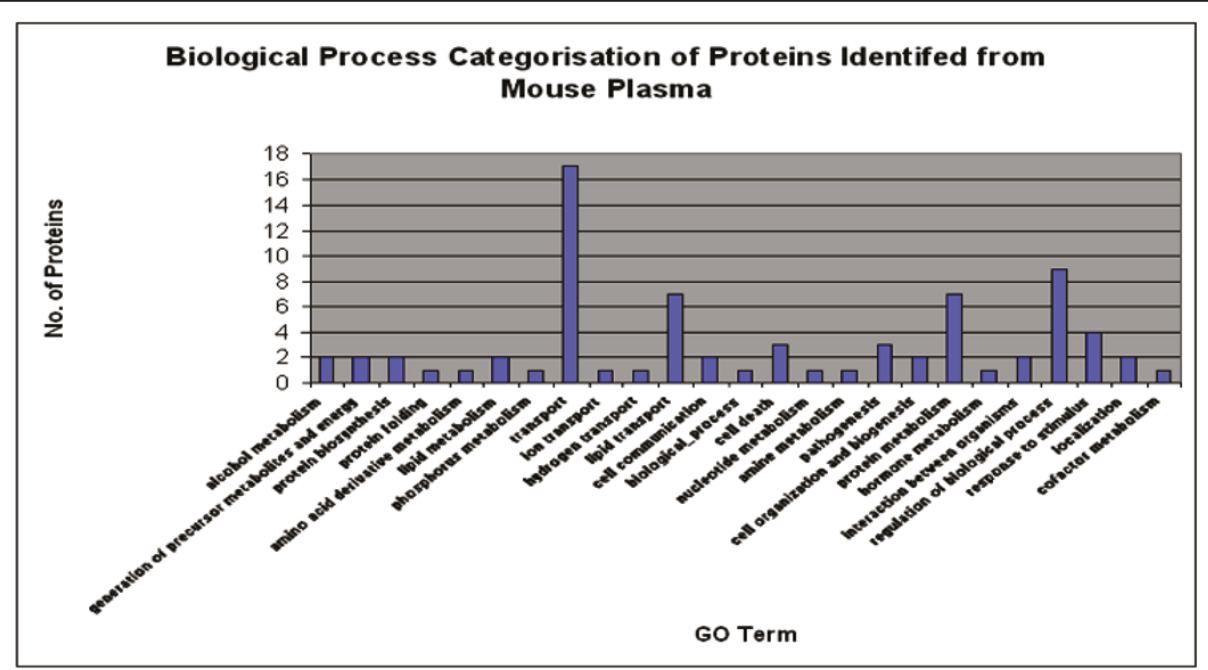

Figure 3 Functional Categorization of 106 proteins identified based on gene ontology classification for Biological Process. The Gene Ontology (GO) numbers were derived from Protein Information Resource (PIR) -http://pir.georgetown.edu/ Batch retrieval tool. This tool converted the GI NCBInr accession numbers to GO numbers and then used GO slim to categorize the proteins. Another 47 identified proteins were unmatched to $\mathrm{GO}$ and not included in this graph.

components of mouse plasma may provided insights into these complications.

Of the 157 proteins identified 54 were uniquely expressed in the plasma from infected mice. Most of the differentially or uniquely expressed proteins in plasma are acute phase proteins that are widely thought to indicate generalized inflammation and apoptosis. Other proteins identified suggest that the parasite may cause the host to express proteins that support cell invasion and reduce apoptosis, which would lead to better survival of infected red blood cells.

One of the unique proteins identified was similar to spectrin non-erythroid alpha chain brain protein (spot 36 infected gel map). This protein has recently been shown to correlate with severity of CM in Gabonese children [16]. Another of the proteins identified as unique to plasma from infected mice was related to macrophage galcotose-type C-type lectin 2 (MGL2) (Spot 12 and 14). MGL2 is induced in diverse populations of activated macrophages, including peritoneal macrophages during infection with the protozoan, Trypanosoma brucei brucei or the helminth, Taenia crassiceps; and alveolar macrophages in a mouse model of allergic asthma [17]. Raes et al [17] also demonstrated that in vitro, interleukin-4 (IL-4) and IL-13 up-regulate MGL2 expression and that in vivo, induction of MGL2 is dependent on IL-4 receptor signaling. Moreover, expression of MGL on human monocytes is also upregulated by IL-4. The study concluded that macrophage galactose-type $\mathrm{C}$-type lectins represent novel surface markers for murine and human activated macrophages and could be important markers of immune response in murine malaria.

Another of the proteins identified as unique to plasma drawn from infected mice is Baculoviral Inhibitor of Apoptosis (IAP) repeat-containing protein 3, which is an apoptotic suppressor. This protein interacts with tumour necrosis factor (TNF) receptor associated factors 1 and 2 to form an heteromeric complex, which is then recruited to the TNF receptor 2 [18]. The presence of this protein could be protective, trying to abrograte apoptosis caused by a massive local release of TNF in both murine liver cells during malarial infection $[19,20]$ and in endothelial cells from human cerebral malaria $[21,22]$. Moreover the identification of a protein similar to hormone-regulated proliferation-associated protein 20 (HRPAP20) (spot 82 infected) suggests that in murine malaria suppression of apoptosis plays a key role in disease progression.

Two proteins associated with mediation of anti -inflammation, Apolipoprotein A1 (spot 42 infected depleted) and heparan sulfate transferase 1 (spot 99 infected) were also differentially expressed strengthening the idea that the mouse model is predominantly an inflammatory disease.

There were 49 proteins expressed in the control gels that were absent from malaria infected samples. These included transthyretin (spot 72 control gel), which sometimes acts as a retinol carrier through an association with retinol binding protein [23]. It is normally found at high concentrations in plasma and the fact that it was not detected in the plasma from infected mice 
would suggest that the levels in rodent malaria are too low to detect or some protein modification had occurred. Transthyretin is an acute phase protein that decreases during an acute phase response [24]. Together with other acute phase proteins such as transferrin and albumin, these proteins decrease during an acute phase response and have no apparent immune function [24]. Their main role is to transport nutrients therefore; their reduction during infection and inflammation may lower the concentration of specific nutrients. To support this hypothesis it has been shown that the serum concentration of retinol, the alcohol form of vitamin A, decreases during malarial infections. This reduction has been characterized as a direct consequence of the inflammatory response to Plasmodium infections $[25,26]$.

Previously, several proteins have been associated with a reduction in retinol [27-29]. The proteomic results here suggest that transthyretin may be a useful predictor of plasma retinol during malarial infection. This information would be useful because the inclusion of a measure of the acute phase response would help interpret plasma retinol concentrations during malarial infection [25,27].

\section{Conclusion}

This study goes some way to validate the technique of proteomics for characterising proteins differentially expressed during disease in this case with the P. berghei ANKA mouse malaria model. The results here suggest that apoptosis and inflammation play a major role in disease progression and also suggest that qualitative analysis of markers of activated macrophages could help elucidate their role in controlling murine malaria as well as confirming the relevance of macrophages in developing host immunity to this infection. As a whole, the study provides a "proof of concept" on use of plasma proteomics to help understand host response to the malaria parasite.

\section{Acknowledgements}

We thank the Director of Kenya Medical Research Institute (KEMRI) for permission to publish this work. G.O. Kokwaro was supported by a Research Capability Strengthening Grant from W.H.O. (TDR/MIM grant no. 980074). E. N. Gitau was a PhD student supported y the KEMRI/Wellcome Trust Research Programme Kenya. Dr C.R.J.C. Newton (050533) was supported by The Wellcome Trust, United Kingdom

\footnotetext{
Author details

${ }^{1}$ KEMRI-Wellcome Trust Collaborative Programme, Centre for Geographic Medicine Coast, Kilifi, Kenya. ${ }^{2}$ Liverpool School of Tropical Medicine, Pembroke Place, Liverpool, UK. Institute of Child Health, University College of London, London, UK. ${ }^{4}$ Department of Pharmaceutics and Pharmacy Practice, School of Pharmacy, University of Nairobi, P. O. Box 19676-00202 (KNH), Nairobi, Kenya. ${ }^{5}$ African Centre for Clinical Trials, P. O. Box 2288-00202 (KNH), Nairobi, Kenya. ${ }^{6}$ Consortium for National Health Research, P.O. Box 29832-00202 (KNH), Nairobi, Kenya.
}

\section{Authors' contributions}

EG carried out the proteomic experiments and drafted the paper. CJRC, SAW and GK participated in the design of the study and helped draft the manuscript. All authors read and approved the final manuscript.

\section{Competing interests}

The authors declare that they have no competing interests.

Received: 25 January 2011 Accepted: 26 July 2011

Published: 26 July 2011

\section{References}

1. WHO: Integrated management of childhood illness: conclusions. WHO Division of Child Health and Development. Bull World Health Organ 1997, 75(Suppl 1):119-128.

2. Bafort JM, Pryor WH, Ramsey JM: Immunization of rats against malaria: a new model. J Parasitol 1980, 66:337-338.

3. Rest JR: Cerebral malaria in inbred mice. I. A new model and its pathology. Trans R Soc Trop Med Hyg 1982, 76:410-415.

4. Thumwood CM, Hunt NH, Clark IA, Cowden WB: Breakdown of the bloodbrain barrier in murine cerebral malaria. Parasitology 1988, 96(Pt 3):579-589.

5. Neill AL, Chan-Ling T, Hunt NH: Comparisons between microvascular changes in cerebral and non-cerebral malaria in mice, using the retinal whole-mount technique. Parasitology 1993, 107(Pt 5):477-487.

6. Reed RC, Verhuel AF, Hunter RL, Udhayakumar V, Louis-Wileman V, Jennings VJ, Jue DL, Wohlhueter RM, Lal AA: Rapid onset of malariainduced mortality by immunizations with lipo-peptides: an experimental model to study deleterious immune responses and immunopathology in malaria. Vaccine 1997, 15:65-70.

7. Kennedy S: Proteomic profiling from human samples: the body fluid alternative. Toxicol Lett 2001, 120:379-384.

8. Laemmli UK: Cleavage of structural proteins during the assembly of the head of bacteriophage T4. Nature 1970, 227:680-685.

9. Blum HE, Haase AT, Vyas GN: Molecular pathogenesis of hepatitis B virus infection: simultaneous detection of viral DNA and antigens in paraffinembedded liver sections. Lancet 1984, 2:771-775.

10. Rabilloud T, Carpentier G, Tarroux P: Improvement and simplification of low-background silver staining of proteins by using sodium dithionite. Electrophoresis 1988, 9:288-291.

11. Neuhoff V, Arold N, Taube D, Ehrhardt W: Improved staining of proteins in polyacrylamide gels including isoelectric focusing gels with clear background at nanogram sensitivity using Coomassie Brilliant Blue G250 and R-250. Electrophoresis 1988, 9:255-262.

12. Perkins DN, Pappin DJ, Creasy DM, Cottrell JS: Probability-based protein identification by searching sequence databases using mass spectrometry data. Electrophoresis 1999, 20:3551-3567.

13. Neill AL, Hunt NH: Pathology of fatal and resolving Plasmodium berghei cerebral malaria in mice. Parasitology 1992, 105(Pt 2):165-175.

14. Polder TW, Eling WM, Curfs JH, Jerusalem CR, Wijers-Rouw M: Ultrastructural changes in the blood-brain barrier of mice infected with Plasmodium berghei. Acta Leiden 1992, 60:31-46.

15. Hearn J, Rayment N, Landon DN, Katz DR, de Souza JB: Immunopathology of cerebral malaria: morphological evidence of parasite sequestration in murine brain microvasculature. Infect Immun 2000, 68:5364-5376.

16. Guiyedi V, Chanseaud Y, Fesel C, Snounou G, Rousselle JC, Lim P, Koko J, Namane A, Cazenave PA, Kombila M, Pied S: Self-reactivities to the nonerythroid alpha spectrin correlate with cerebral malaria in Gabonese children. PLOS ONE 2007, 2:e389.

17. Raes G, Brys L, Dahal BK, Brandt J, Grooten J, Brombacher F, Vanham G, Noel W, Bogaert P, Boonefaes T, Kindt A, Van den Bergh R, Leenen PJ, De Baetselier P, Ghassabeh GH: Macrophage galactose-type C-type lectins as novel markers for alternatively activated macrophages elicited by parasitic infections and allergic airway inflammation. J Leukoc Biol 2005, 77:321-327.

18. Liston P, Lefebvre C, Fong WG, Xuan JY, Korneluk RG: Genomic characterization of the mouse inhibitor of apoptosis protein 1 and 2 genes. Genomics 1997, 46:495-503.

19. Guha M, Choubey V, Maity P, Kumar S, Shrivastava K, Puri SK, Bandyopadhyay U: Overexpression, purification and localization of 
apoptosis related protein from Plasmodium falciparum. Protein Expr Purif 2007, 52:363-372.

20. Guha M, Kumar S, Choubey V, Maity P, Bandyopadhyay U: Apoptosis in liver during malaria: role of oxidative stress and implication of mitochondrial pathway. Faseb J 2006, 20:1224-1226.

21. Combes V, Coltel N, Faille D, Wassmer SC, Grau GE: Cerebral malaria: role of microparticles and platelets in alterations of the blood-brain barrier. Int J Parasitol 2006, 36:541-546.

22. Wassmer SC, Moxon CA, Taylor T, Grau GE, Molyneux ME, Craig AG: Vascular endothelial cells cultured from patients with cerebral or uncomplicated malaria exhibit differential reactivity to TNF. Cell Microbiol 2011, 13:198-209.

23. Sasaki H, Yoshioka N, Takagi Y, Sakaki Y: Structure of the chromosomal gene for human serum prealbumin. Gene 1985, 37:191-197.

24. Schreiber G, Tsykin A, Aldred AR, Thomas T, Fung WP, Dickson PW, Cole T, Birch $\mathrm{H}$, De Jong FA, Milland J: The acute phase response in the rodent. Ann N Y Acad Sci 1989, 557:61-85, discussion 85-66.

25. Thurnham DI, Singkamani R: The acute phase response and vitamin A status in malaria. Trans R Soc Trop Med Hyg 1991, 85:194-199.

26. Tabone MD, Muanza K, Lyagoubi M, Jardel C, Pied S, Amedee-Manesme O, Grau GE, Mazier D: The role of interleukin-6 in vitamin A deficiency during Plasmodium falciparum malaria and possible consequences for vitamin A supplementation. Immunology 1992, 75:553-554.

27. Filteau SM, Morris SS, Abbott RA, Tomkins AM, Kirkwood BR, Arthur P, Ross DA, Gyapong JO, Raynes JG: Influence of morbidity on serum retinol of children in a community-based study in northern Ghana. Am J Clin Nutr 1993, 58:192-197.

28. Das BS, Thurnham DI, Das DB: Plasma alpha-tocopherol, retinol, and carotenoids in children with falciparum malaria. Am J Clin Nutr 1996, 64:94-100.

29. Friis H, Mwaniki D, Omondi B, Muniu E, Magnussen P, Geissler W, Thiong'O F, Michaelsen KF: Serum retinol concentrations and Schistosoma mansoni, intestinal helminths, and malarial parasitemia: a cross-sectional study in Kenyan preschool and primary school children. Am J Clin Nutr 1997, 66:665-671.

doi:10.1186/1475-2875-10-205

Cite this article as: Gitau et al:: Global proteomic analysis of plasma from mice infected with Plasmodium berghei ANKA using two dimensional gel electrophoresis and matrix assisted laser desorption ionization-time of flight mass spectrometry. Malaria Journal 2011 10:205.

\section{Submit your next manuscript to BioMed Central and take full advantage of:}

- Convenient online submission

- Thorough peer review

- No space constraints or color figure charges

- Immediate publication on acceptance

- Inclusion in PubMed, CAS, Scopus and Google Scholar

- Research which is freely available for redistribution

Submit your manuscript at www.biomedcentral.com/submit 